\title{
Technological and Nutritive Characterization of "Queijo de Porco" Sausage Traditionally Produced and Commercialized in Southern Brazil
}

\author{
Brazilian "Queijo de Porco" sausages
}

\author{
OLIVEIRA, Cristiane Ayala de. Doutora/Tecnóloga em Agroindústria \\ Instituto Federal de Educação, Ciência e Tecnologia do Sertão Pernambucano - Campus Salgueiro. BR 232, Km \\ 504, sentido Recife, Zona Rural - Salgueiro - Pernambuco - Brasil. CEP: 56.000-000 / Telefone: (87) 9966.43349/ \\ E-mail: cristiane.ayala@ifsertao-pe.edu.br
}

\author{
RODRIGUES, Lorena Mendes. Mestre/Tecnóloga em Alimentos \\ Universidade Federal de Lavras - UFLA - Departamento de Ciência dos Alimentos - DCA. Câmpus Universitário, \\ Caixa Postal 3037 - Lavras - Minas Gerais - Brasil. CEP: 37.200-000 / Telefone: (35) 38291403 / E-mail: \\ lorii_mendes@hotmail.com
}

\begin{abstract}
ANDRADE, Monalisa Pereira Dutra. Doutora/Engenheira de Alimentos
Instituto de Ciência e Tecnologia, Universidade Federal dos Vales de Jequitinhonha e Mucuri (UFVJM), Campus JK, Diamantina, Minas Gerais, 39100-000/ Telefone: (38) 3532-8409/ E-mail: monalisadutra@ict.ufvjm.edu.br
\end{abstract}

RAMOS, Alcinéia de Lemos Souza. Doutora/Engenheira de Alimentos

Universidade Federal de Lavras - UFLA - Departamento de Ciência dos Alimentos - DCA. Câmpus Universitário, Caixa Postal 3037 - Lavras - Minas Gerais - Brasil. CEP: 37.200-000 / Telefone: (35) 38291403 / E-mail:

alcineia@dca.ufla.br

RAMOS, Eduardo Mendes. Doutor/Engenheiro de Alimentos

Universidade Federal de Lavras - UFLA - Departamento de Ciência dos Alimentos - DCA. Câmpus Universitário, Caixa Postal 3037 - Lavras - Minas Gerais - Brasil. CEP: 37.200-000 / Telefone: (35) 38291403 / E-mail:

emramos@dca.ufla.br

\section{ABSTRACT}

The use of byproducts is of great importance to the meat industry, as it adds value to a plentiful raw material and provide an increase in the nutrients content of formulated products. In Brazil, the manufacturing of such products is not standardized not being known its technical characteristics and nutritional quality. The purpose of this paper was provide technical and nutritional information of a traditional southern Brazilian sausage elaborated with edible pork byproducts ("Queijo de Porco") to support the elaboration of a standardized legislation to control and ensure the high quality and genuineness of this product. Sausages from different brands marketed in the state of Rio Grande do Sul were analyzed for $\mathrm{pH}$, proximal composition, water activity, salt and residual nitrite content, total and nitrous heme pigments, mineral (calcium, sodium and iron) and collagen content, fatty acids composition and texture profile analysis. There were significant differences $(P<0.05)$ correlated to manufacture brand, except for the mean protein $(13.69 \%)$, ash $(3.78 \%)$ and salt (2.18\%) contents. Comparing with others Brazilian pork products, this sausage was characterized by similar fatty acid content. The products had high calcium $(5.22 \mathrm{mg} / 100 \mathrm{~g})$ and iron $(30.32 \mathrm{mg} / 100 \mathrm{~g})$ contents, with a good polyunsaturated/saturated fatty acids ratio $(0.48)$ and low atherogenic $(0.43)$ and thrombogenic (1.0) indexes. The results obtained indicate that "Queijo de Porco" is a more healthful product than some pork products produced in Brazil, permitting the industries of the sector add value to less specialized cuts of pork, but at the same time provide a product with considerable nutritional value.

Palavras-chave: Meat byproducts, jelly products, fatty acid profile, minerals, nutritional value, texture. 
OLIVEIRA,C. A. de; RODRIGUES, L. M.; ANDRADE, M. P. D.; RAMOS, A. de L. S.; RAMOS, E. M. (2019) Technological and Nutritive Characterization of "Queijo de Porco" Sausage Traditionally Produced and Commercialized in Southern Brazil

\section{Introduction}

The byproducts of pork industry represent approximately $10 \%$ of the value of live cattle, and are normally composed by blood, retails of beef cuts, head and feet, besides offal, such as liver and heart. The utilization of these byproducts and the incorporation of large number of retails from boning to prepare meat products (mainly sausages), makes it interesting from the economic point of view by adding value to a plentiful raw material and at a low commercial value, in addition to providing an increase in the protein content of the products.

In Colombia, a cooked sausage exclusively constituted of edible animal by-products is called "Queijo de Puerco", processed from head meat and pig skin, adding offal, ingredients and additives permitted by legislation. In other countries similar products are mentioned, in which the same principle is used: products that require a pre-gelatinization to get their format. In England, there is an account of a similar product to "Queijo de Porco" called "Brawn". In other countries of English language, the term used for it is "Head Cheese", while in Spanish countries it is called "Queso de Cabeza". In Poland, its original name is "Salceson". In Germany, it is known as "Presskopf" (pressed) or "Sülze", which generally have vinegar added during the cooking.

In Southern of Brazil, the "Queijo de Porco" seems to have been originated from a German recipe, due to the German colonization, especially in Rio Grande do Sul state. In this region, "Queijo de Porco" is a sausage that has a great acceptance by the consumers. However, the uniformity of this product is practically non-existent during its preparation by different meat processors industries, since there are no legislative standards for this product in Brazil. In another American countries, such as Colombia , Uruguay , Mexico , Costa Rica and Ecuador, which have a tradition for production and consumption of "Queijo de Porco", there is a specific regulation for preparing this type of product; however, only in Mexico and in Uruguay, there is a legislation that determines its standards of production and quality.

Although its production and consumption generalized in the countries cited, the scientific knowledge of this type of sausage is limited, and the available information in scientific literature refers to only some microbiological aspects and food security. In general, the characteristics of this meat derivate is not well known and the available data about "Queijo de Porco" produced and commercialized in Brazil are shortage. Therefore, this work had the objective of evaluating the technological and nutritional characteristics of "Queijo de Porco" produced and commercialized in the state of Rio Grande do Sul, where the preparation and consumption of this product is culturally widespread.

\section{Material and Methods}

\section{Samples}


OLIVEIRA,C. A. de; RODRIGUES, L. M.; ANDRADE, M. P. D.; RAMOS, A. de L. S.; RAMOS, E. M. (2019) Technological and Nutritive Characterization of "Queijo de Porco" Sausage Traditionally Produced and Commercialized in Southern Brazi

Four traditional brands of "Queijo de Porco" from four different regions of the state of Rio Grande do Sul, Brazil, were collected in retail markets. All samples came from establishments with registration of State or Federal Inspection. For each brand studied, five samples from different manufacturing lots were collected, representing the repetitions and resulting in 20 experimental units.

\section{Physical and chemical analysis}

The sausages were submitted to physical and chemical analysis of total moisture (AOAC 950.46B), fat (AOAC 960.39), protein (AOAC 981.10, using 6.25 as conversion factor) and ash (AOAC 950.46) contents (in triplicate) using the Association of Official Analytical Chemists procedures . Total carbohydrate was obtained by difference (total weight minus moisture, protein, fat and ash). Average $\mathrm{pH}$ values were measured using a potentiometer DM 20 (Digimed, São Paulo, Brazil) by inserting a combined penetration electrode into the product at three different points. Water activity was measured using an Aqualab ${ }^{\circledR}$ Water Activity Meter CX2 device (Decagon Devices Inc., WA, USA).

Samples were also analyzed for: minerals $(\mathrm{mg} / 100 \mathrm{~g})$ iron $(\mathrm{Fe})$, sodium $(\mathrm{Na})$ and calcium (Ca), by wet digestion and atomic absorption spectroscopy detection (AOAC 985.35) ; salt content (\% chlorine as sodium chloride) and residual sodium nitrite (mg NaNO2/kg of sample), using AOAC official methods 935.47 and 973.31 , respectivilly; and for total heme pigments (THP; $\mu \mathrm{g}$ acid hematin/g of sample) and nitroso heme pigments (NHP; $\mu \mathrm{g}$ hematin/g of sample), using the acetone extraction method of Hornsey described by Ramos and Gomide [9]. The NHP was also expressed as percentage of total pigment converted to nitroso pigment.

The collagen concentration was determined from the hydroxyproline content according to the AOAC method 990.26 , being converted to collagen content $(\mathrm{g} / 100 \mathrm{~g})$ with a factor 0 f 7.25 .

\section{Texture profile analysis}

Sausages were tested by texture profile analysis (TPA) using a TA.XT2i Texture Analyzer (Stable Micro Systems Ltd., Surrey, England) of $25 \mathrm{kgf}$ cell as described by . Six cores (cubes with 25 $\mathrm{mm}$ edge) samples were compressed twice to $50 \%$ of their original height, at room temperature, with compression flat cylindrical aluminum probe (36 mm diameter). A cross-head speed of 180 $\mathrm{mm} / \mathrm{min}$ was applied. There was no time to rest between the two cycles of compression. Force time curves were recorded and the attributes were calculated as : hardness $(\mathrm{N})$, peak force required for first compression; springiness $(\mathrm{mm})$, distance sample recovers after first compression; adhesiveness ( $\mathrm{N} \times \mathrm{mm})$, the negative force area for the first bite representing the work necessary to pull the compressing plunger away from the sample; cohesiveness, ratio of positive force area during the second compression to that in the first compression; and chewiness $(\mathrm{N} \times \mathrm{mm})$, the product of hardness, cohesiveness and springiness. 
OLIVEIRA,C. A. de; RODRIGUES, L. M.; ANDRADE, M. P. D.; RAMOS, A. de L. S.; RAMOS, E. M. (2019) Technological and Nutritive Characterization of "Queijo de Porco" Sausage Traditionally Produced and Commercialized in Southern Brazil

Lipid profile

For the analysis of fatty acids (FAs), the total lipids extraction and the FA methyl esters preparation were performed according to Hartman and Lago [10]. Briefly, the fatty acids were extracted in a chloroform/methanol solution, saponified with a methanolic $\mathrm{NaOH}$ and methylated under acidic conditions by adding a solution of ammonium chloride, methanol, and sulphuric acid. The FA methyl esters were submitted to gas liquid chromatography on a GC-2010 model chromatographer (Shimadzu Corporation, Kyoto, Japan) equipped with a flame ionization detector and a $100 \mathrm{~m}$ capillary column of polyethylene glycol, coupled to software developed by the manufacturer (Supelco SP-2560, Bellefonte, PA, USA). The operational parameters were as described by Vicente-Neto et al. [11] and the identification of peaks in the sample chromatograms was performed by comparing their retention time with the standard chromatogram (Supelco ${ }^{\text {TM }} 37$ Component FAME Mix, Bellefonte, PA, USA), which consisted of a mixture of 37 FA methyl esters.

Individual FA was expressed as a percentage of the total area of the identified FA and was categorized as saturated (SFA), monounsaturated (MUFA) and polyunsaturated (PUFA).

The atherogenic and thrombogenic indexes were calculated according to Ulbricht and Southgate [12] as follows:

Atherogenic index $=[(4 \times 14: 0)+16: 0] /(18: 2 n 6+18: 3 n-3+18: 3 n 6+$ IMUFA $)$.

Thrombogenic index $=[14: 0+16: 0+18: 0] /[(0.5 \times$ IMUFA $)+(0.5 *(18: 2 n 6+18: 3 n 6))+(3 \times 18: 3$ $n 3)+((18: 3 n 3 /(18: 2 n 6+18: 3 n 6)))]$.

\section{Statistical Analysis}

The experiment was conducted in a completely randomized design with four treatments (samples) and three replicates with samples from different lots. The resulting data were tested by F-test (ANOVA) and, when was significant $(P<0.05)$, the means were separated using Tukey's test. Statistical analyses were performed using the SAS statistical (SAS Institute Inc., Cary, NC, USA) package, version 9.2 .

\section{Results and Discussion}

\section{Technological characterization}

The technological characterization data (Table 1 ) shows that the four samples are quite different, which is consistent with a previous visual assessment (Fig. 1). All of the analyzed samples were bought in packages labeled "Queijo de Porco", but the results for the proximal composition were compared to the criteria established for "Fiambres" by the Brazilian legislation due to inexistence of proper legislation. Obviously, this is not the best classification for this type of 
OLIVEIRA,C. A. de; RODRIGUES, L. M.; ANDRADE, M. P. D.; RAMOS, A. de L. S.; RAMOS, E. M. (2019)

Technological and Nutritive Characterization of "Queijo de Porco" Sausage Traditionally Produced and Commercialized in Southern Brazil

product, once "Fiambre" is defined as an industrialized meat product obtained from meat of one or more butcher's animal species and the regulation limits, for instance, the content of offal to maximum of $10 \%$. According to the Brazilian legislation , "offal" are organs and viscera of butcher's animals used for feeding humans (crumbs, tongues, heart, liver, kidney, rumen, reticulin), besides "mocotós" and "rabada". In products, such as "Queijo de Porco", offal is essentially the main raw material used in the formulation.

In general, all samples were within the limits established for moisture (maximum of $70 \%$ ) and protein (minimum of $12 \%$ ) contents by the Brazilian legislation. Despite having almost no complete data about the chemical composition of "Queijo de Porco", some authors show few parameters of composition for similar products. Ockerman [15] cites 16 formulations of "Head Cheese (Brawn)" varying between 38.8 and $62.7 \%$ of moisture and between 13.0 and $23.2 \%$ of protein. Of the few countries that set out standards for products such as "Queijo de Porco", maximum values of $70 \%$ of moisture and minimum values of $12 \%$ of protein are established by the Ecuadorian legislation, while the Mexican legislation establishes the maximum moisture content of $50 \%$.

Among the brands assessed, significant differences were not found $(P>0.05)$ for protein contents, but there was a difference $(P<0.05)$ in the moisture content. However, this variation is related to differences in the ingredients and raw materials used. It is noted, for example, the samples with lower moisture content (brands $A$ and $B$ ), also present higher fat contents, and/or higher quantity of carbohydrates than the other brands ( $B$ and $C$ ). In the Brazilian regulation, it is not established the maximum percentage of fats for "fiambres", while the Ecuadorian regulation determines a maximum value of $30 \%$ and the Mexican regulation a maximum of $50 \%$. However, fat contents of similar products cited in the literature vary a lot, being found works with values between 15.4 and $32.8 \%$.

Table 1. Mean ( \pm standard deviation) of the technological characteristics of the analyzed "Queijo de Porco" samples.

\begin{tabular}{llllll}
\hline \multicolumn{1}{c}{ Characteristics } & \multicolumn{1}{c}{ Brand A } & \multicolumn{1}{c}{ Brand B } & Brand C & Brand D & Mean \\
\hline Proximal composition & & & & & \\
Moisture (\%) & $49.61 \pm 6.55^{a}$ & $53.58 \pm 4.97^{a b}$ & $58.48 \pm 3.06^{b}$ & $60.20 \pm 3.74^{b}$ & $55.47 \pm 6.16$ \\
Protein (\%) & $11.96 \pm 1.75$ & $14.15 \pm 2.18$ & $14.83 \pm 2.48$ & $13.81 \pm 1.92$ & $13.69 \pm 2.24$ \\
Fat (\%) & $22.78 \pm 5.43^{b}$ & $20.36 \pm 3.03^{b}$ & $18.30 \pm 1.13^{a b}$ & $13.32 \pm 2.33^{a}$ & $18.69 \pm 4.75$ \\
Ash (\%) & $3.75 \pm 0.43$ & $4.22 \pm 1.95$ & $3.56 \pm 1.29$ & $3.59 \pm 0.59$ & $3.78 \pm 1.18$ \\
Carbohydrates (\%) ${ }^{*}$ & $11.90 \pm 3.85^{b}$ & $7.69 \pm 4.87^{a b}$ & $4.83 \pm 3.22^{a}$ & $9.08 \pm 4.71^{a b}$ & $8.36 \pm 4.72$ \\
pH & $6.00 \pm 0.41^{b}$ & $4.78 \pm 0.36^{a}$ & $5.89 \pm 0.72^{b}$ & $5.96 \pm 0.60^{b}$ & $5.66 \pm 0.52$ \\
Water activity & $0.936 \pm 0.001^{a}$ & $0.959 \pm 0.002^{b}$ & $0.951 \pm 0.001^{c}$ & $0.950 \pm 0.002^{c}$ & $0.950 \pm 0.009$ \\
Chlorine (\%) & $1.71 \pm 0.36$ & $2.62 \pm 0.87$ & $2.08 \pm 0.33$ & $2.31 \pm 0.51$ & $2.18 \pm 0.62$ \\
Collagen (\%) & $4.84 \pm 0.35^{b}$ & $3.92 \pm 0.87^{a}$ & $3.96 \pm 0.33^{a b}$ & $3.64 \pm 0.50^{a}$ & $4.09 \pm 0.69$ \\
THP ( $\mu$ g hematin. $\left.{ }^{-1}\right)$ & $89.02 \pm 7.36^{a b}$ & $89.67 \pm 3.07^{a b}$ & $78.57 \pm 6.37^{b}$ & $101.76 \pm 2.79^{a}$ & $89.76 \pm 9.48$ \\
NHP $\left(\mu g\right.$ hematin. $\left.{ }^{-1}\right)$ & $29.72 \pm 5.37^{a b}$ & $34.90 \pm 0.40^{a}$ & $24.30 \pm 3.10^{b}$ & $36.60 \pm 2.67^{a}$ & $31.40 \pm 5.54$
\end{tabular}


OLIVEIRA,C. A. de; RODRIGUES, L. M.; ANDRADE, M. P. D.; RAMOS, A. de L. S.; RAMOS, E. M. (2019)

Technological and Nutritive Characterization of "Queijo de Porco" Sausage Traditionally Produced and Commercialized in Southern Brazil

NHP (\% of THP)

$33.50 \pm 6.50$

$38.95 \pm 1.21$

$38.84 \pm 1.50$

$35.97 \pm 2.60$

$36.83 \pm 2.57$

$\mathrm{NO}_{2} \mathrm{R}\left(\mathrm{mg} \cdot \mathrm{Kg}^{-1}\right)$

$81.84 \pm 2.63^{b}$

$128.52 \pm 4.35^{a} 111.85 \pm 14.62^{a} 81.07 \pm 0.57^{b}$

$100.82 \pm 23.37$

Texture profile analysis

Hardness ( $\mathrm{N}$ )

$12.88 \pm 2.35^{c}$

$6.02 \pm 0.96^{a b}$

$5.92 \pm 1.05^{a}$

$6.09 \pm 1.35^{a b}$

$7.72 \pm 3.43$

Cohesiveness

$0.74 \pm 0.13^{c}$

$0.53 \pm 0.26^{a b}$

$0.50 \pm 0.22^{a}$

$0.55 \pm 0.13^{a b}$

$0.58 \pm 0.10$

Adhesiveness $\left(10^{2} \mathrm{~N} . \mathrm{mm}\right)$

$1.05 \pm 7.65$

$1.09 \pm 10.02$

$0.3 \pm 7.47$

$0.82 \pm 2.40$

$0.81 \pm 0.36$

Springiness $(\mathrm{mm})$

$11.87 \pm 0.32$

$12.19 \pm 0.94 \quad 11.76 \pm 0.57$

$11.97 \pm 0.72$

$11.95 \pm 0.18$

Chewiness (N.mm)

$114.31 \pm 50.09^{b} 40.45 \pm 26.67^{a} 35.32 \pm 27.23^{a}$

$41.04 \pm 19.38^{a} 57.78 \pm 37.77$

THP = total heme pigment; NHP = nitrosoheme pigment; NO2R = nitrite residual.

${ }^{*}$ Calculated as total weight minus moisture, protein, fat and ash. ${ }^{* *}$ As sodium chloride $(\mathrm{NaCl})$.

${ }^{a-c}$ Means followed by different letters in the same row are different $(P<0.05)$ by the Tukey's test.
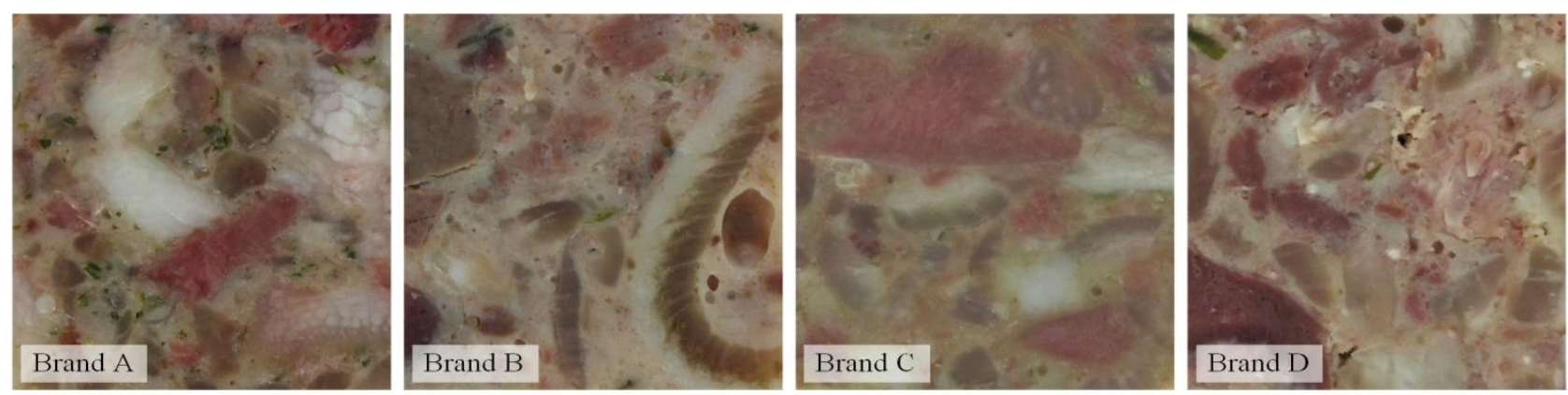

Figure 1.Appearance of the four brands of "Queijo de Porco" from different regions of the state of Rio Grande do Sul, Brazil.

For carbohydrates, the Brazilian legislation establishes $10 \%$ as maximum content, including starch (maximum of 5\%) added, where only brand "A" extrapolated this limit. The variations observed for carbohydrates among the brands can be from the differences in the quantity of hydrocolloids added to the product in order to help in the capacity of water retention, increasing the yield and reducing costs.

Significant differences were not found $(P>0.05)$ for the value of ashes among the four brands studied. The Brazilian legislation does not determine the limits for the fixed mineral residue of "fiambres", while according to the Ecuadorian regulations the maximum ashes content must be of $3.5 \%$, very close to the average $(3.78 \%)$ observed in this experiment.

In relation to $\mathrm{pH}$ and water activity (Aw), statistically significant differences were observed $(P<0.05)$ among the four brands assessed, which can be from differences in the quantity and type of ingredients used. There are no limits defined for $\mathrm{pH}$ and $\mathrm{Aw}$ values according to the Brazilian legislation for "fiambres", but based on the Ecuadorian legislation Queso de cerdo" must have pH values varying between 5.90 and 6.20. Cooked sausages, as well as cooked ham, regularly exhibit pH value of 6.00 and $\mathrm{Aw}$ values of around 0.96-0.98. The $\mathrm{pH}$ values close to 6.0 are obtained from adding ingredients with high $\mathrm{pH}$ values, especially phosphates, used in favor of water retention through the proteins of meat mass. Generally, phosphate blends for meat products exhibit a pH value around 9.0-9.3. Moreover, the addition of sugar or salt (binding of water through ions) and fat 
OLIVEIRA,C. A. de; RODRIGUES, L. M.; ANDRADE, M. P. D.; RAMOS, A. de L. S.; RAMOS, E. M. (2019) Technological and Nutritive Characterization of "Queijo de Porco" Sausage Traditionally Produced and Commercialized in Southern Brazil

(less water added) on meat products contributes to the reduction of the Aw values. In general, the products assessed were within the expected range of $\mathrm{pH}$ and $\mathrm{Aw}$, but brand $\mathrm{B}$ presented a very low $\mathrm{pH}$, which can indicate excess of acidity in the product, characteristic of microbial growth.

Nevertheless, statistical differences for chlorides contents were not observed $(P>0.05)$ among the four brands studied (Table 1), being the products added, an average of $2.18 \%$ of salt. Despite having a recent mobilization of the governmental bodies to try to decrease the salt content in the foods in Brazil, there is not a legal instrument yet to limit the concentration of sodium chloride in meat products.

Despite being small, differences were found $(\mathrm{P}<0.05)$ in collagen content and PHT among the brands (Table 1), which can probably be due to differences in the formulation in relation to the addition of collagenous raw material. "Queijo de Porco" and other jellied products, such as head cheese (brawn) and souse, use high collagen meat sources such as pork skins and head trimmings or gelatin. These products are often made from other edible meat byproducts (visually perceptible in the products Fig. 1) like pork tongues, hearts, cheeks, ears and snouts, which give different ratios of collagen content and capacity to color (heme pigment content). According to Ockerman and Hansen [1], liver and kidney have high collagen content and high colour parameter; tongue has a high collagen content and an average colour value; tripe and trimmings from the head area are also high in collagen content, but very low to medium in colour values; and hearts have an average in collagen content, but high colour parameter. Of the byproducts, pork skin is the raw material with high collagen content more used for preparation of this type of product. Pork skins and others collagen-rich raw materials are utilized as a binding substance for jellied products, since heating it to $70{ }^{\circ} \mathrm{C}$ yielded gels with increased water binding and results in a stable firm product. Pork skin gelatin also may be used as the binding agent in jellied products.

Despite the differences observed $(\mathrm{P}<0.05)$ in PHT content, they were not sufficient to promote significant differences $(P>0.05)$ on the percentage of total pigment converted to nitrous pigment (nitrosyl hemochrome). This conversion indicates the degree of cured color efficiency: well-cured meats typically have higher than $80 \%$ of total pigment in the nitrous heme form . Pegg and Shahidi [17] point out the final color of the cured product depends on the mixture of convenient quantities of nitrite salts with heme pigment existent, which must be present in sufficient quantity to verify the pinkish color to the meat and its products. In the case of "Queijo de Porco" and similar products, edible byproducts (liver, heart, kidney and tongue) are the main raw materials that are cured and contribute to pigmentation but are present in the product in pieces (Fig. 1). The mass that empowers texture to these products is a little pigmented due to the use of large quantities of collagenous raw materials, such as pork skins, which can have contributed for low conversion percentage of total heme pigments for nitrosyl hemochrome.

The nitrite residual level differences observed $(P<0.05)$ among products may be due to differences in the amount of sodium nitrite added, since a higher concentration of ingoing nitrite means higher residual nitrite amounts. Also may be due to differences in amount and type of raw material and ingredients, which may contain different constituents (e.g., amines and amino acids, sulfhydryl and phenolic compounds, heme pigments, ascorbate or erythorbate) that can interact 
OLIVEIRA,C. A. de; RODRIGUES, L. M.; ANDRADE, M. P. D.; RAMOS, A. de L. S.; RAMOS, E. M. (2019) Technological and Nutritive Characterization of "Queijo de Porco" Sausage Traditionally Produced and Commercialized in Southern Brazil

with nitrite ions. Therefore, these complex nitrite reactions can contribute for the variation in the amount of residual nitrite in meat products. Although significant differences have been verified $(\mathrm{P}<$ 0.05) among the brands of "Queijo de Porco" for the nitrite residual level (Table 1), these values are below the maximum limit of $150 \mathrm{mg} / \mathrm{kg}$ permitted by the Brazilian legislation.

The characteristic of the jellied products is the gelatinous texture. The jelly, which holds the mix together, is derived from the collagen-rich raw materials used. The gelation (swelling) of the collagenous proteins in the presence of water during the cooking favors water retention and yield of the product, but it also contributes for a harder texture and a better sliceable. Thus, the difference among the samples in the percentage of collagen contributed for the difference $(\mathrm{P}<$ 0.05 ) observed in the parameter values of hardness and cohesiveness (Table 1). Once the values of flexibility were not different $(P>0.05)$ among the samples, the highest values of hardness and cohesiveness of the samples with higher collagen content also reflected in the highest values of chewiness, since it is a product of hardness, cohesiveness and springiness.

\section{Nutritional value}

Livestock products not only provide high-value protein but are also important sources of a wide range of essential micronutrients, in particular minerals such as iron and zinc, and vitamins such as vitamin A. Thus, the first consideration to be taken in relation to the nutritional value of the products is related to the protein content. The raw materials used in the jellied products show a huge proportion of connective tissue, which have low contents of essential aminoacids and absence of tryptophan than those proteins of the muscle tissue. Despite that, the "Queijo de Porco" is a food with high protein (>12 g/100g) content and, due to its low cost, contributes for low income populations to have proteins with a relative biological value to their diet. Furthermore, most internal organs (heart, liver, kidneys, etc) used for the preparation of these products have higher contents of vitamins and minerals than lean meat.

In relation to the mineral contents, significant differences were observed $(P<0.05)$ for calcium, iron and sodium among the four brands of "Queijo de Porco" (Table 2). Of these, sodium is the mineral with the highest concentration, once its presence is mostly due to the addition of sodium chloride $(\mathrm{NaCl})$. However, $\mathrm{NaCl}$ is not the only source of sodium in meat products; most of the additives added to the products, such as curing salts (nitrite/nitrate), ascorbate and polyphosphates are sodium salts.

Table 2. Mean ( \pm standard deviation) of the mineral content $(\mathrm{mg} / 100 \mathrm{~g})$ of the analyzed "Queijo de Porco" samples.

\begin{tabular}{llll}
\hline Samples & Calcium & Iron & Sodium \\
\hline Brand A & $5.45 \pm 5.25^{b}$ & $16.73 \pm 25.50^{c}$ & $2.14 \pm 0.03^{a}$ \\
Brand B & $2.42 \pm 0.20^{c}$ & $25.34 \pm 0.35^{b}$ & $2.19 \pm 0.03^{a b}$ \\
Brand C & $5.24 \pm 2.15^{b}$ & $40.33 \pm 50.2^{a}$ & $3.04 \pm 0.02^{a b}$ \\
Brand D & $7.79 \pm 9.25^{a}$ & $38.90 \pm 1.15^{a}$ & $2.58 \pm 0.01^{a}$
\end{tabular}


OLIVEIRA,C. A. de; RODRIGUES, L. M.; ANDRADE, M. P. D.; RAMOS, A. de L. S.; RAMOS, E. M. (2019)

Technological and Nutritive Characterization of "Queijo de Porco" Sausage Traditionally Produced and Commercialized in Southern Brazil
Mean
$5.22 \pm 2.19$
$30.32 \pm 11.30$
$2.49 \pm 0.41$

$a-b$ Means followed by different letters in the same column are different $(P<0.05)$ by the Tukey's test.

The current concern with excessive sodium intake is due to its association with the increase of blood pressure (hypertension), one of the main risk factors of cardiovascular diseases, such as coronary disease and strokes, besides a lot of complications, like blindness and renal failure, which can come up from a sign of hypertension. The sodium intake exceeds the nutritional recommendations in several industrialized countries. The World Health Organization recommends a maximum daily intake of less than $5 \mathrm{~g}$ sodium chloride per person, which corresponds to approximately $2 \mathrm{~g}$ of sodium per day. Thus, the intake of 100 grams of the samples of "Queijo de Porco" assessed would already be sufficient to exceed the maximum daily recommended by WHO.

In relation to the iron content, the differences observed $(P<0.05)$ among the brands can be originated from differences in the number of internal organs in the formulation of the products, especially when using liver and kidneys, main sources of iron in these products. Intake recommendations for minerals and other nutrients are provided in the Dietary Reference Intakes (DRIs) developed by the Food and Nutrition Board (FNB) at the Institute of Medicine (IOM) of the National Academies (formerly National Academy of Sciences). For iron, the average daily level of intake sufficient to meet the nutrient requirements of nearly all healthy individuals (Recommended Dietary Allowance; RDA) for all age groups of men and postmenopausal women is $8 \mathrm{mg} /$ day; the RDA for premenopausal women is $18 \mathrm{mg} /$ day . Based on the recommendations, 100 grams of any brands of "Queijo de Porco" studied cover the daily needs of adults, while some brands ( $C$ and $D$ ) surpass these limits a lot.

It also has to be considered that the iron present in "Queijo de Porco" is mainly originated from heme pigments (heme iron), which is not only more bioavailable than nonheme iron from plant-based foods, but it is also able to increase the absorption of nonheme iron. For this reason the RDAs for vegetarians groups are 1.8 times higher than for people who eat meat .

In relation to the calcium content, RDA recommended is between 1.0 and $1.3 \mathrm{~g} /$ day for adults and children. Meats (including organs and viscera) and meat products are not nutritional sources of calcium , being the legal concern of the amount of this mineral in the product related to monitoring the adding of mechanically deboned meat (MDM). MDM is defined as meat which has been obtained by mechanical processing, chopping and separation of bones from animals, such as chicken, beef and pork, to be used in the formulation of specific meat product.

The calcium content (dry matter basis - DMB) in manually boned meat is from 0.01 to $0.02 \%$ while the MDM of pork, poultry and beef ranged from $0.06 \%$ to $0.28 \%$. For Brazilian legislation, the MDM can be added at a maximum of $30 \mathrm{~g} / 100 \mathrm{~g}$ in "fiambres", which correspond to an amount of $450 \mathrm{mg} / 100 \mathrm{~g}$ of calcium in DMB. In the products evaluated, the average calcium contents $(<8$ $\mathrm{mg} / 100 \mathrm{~g}$ in $\mathrm{DMB}$ ) are much lower than this limit. In fact, the levels are below than expected in fresh meats, which show the non-usage of MDM in the formulation of these products.

Small differences observed in the lipid profiles were expected among samples (Table 3 ) due to differences in formulations. Monounsaturated fatty acids (MUFAs) were the major constituent 
OLIVEIRA,C. A. de; RODRIGUES, L. M.; ANDRADE, M. P. D.; RAMOS, A. de L. S.; RAMOS, E. M. (2019)

Technological and Nutritive Characterization of "Queijo de Porco" Sausage Traditionally Produced and Commercialized in Southern Brazil

found (mean of 46\%), and the major part of these was oleic acid (18:1), ranging from 40.93 to $43.79 \%$. These proportions was similar to the Brazilian pork products, sausage (“linguiça Toscana”), salami ("Italian type") and traditional and restructured ("presunto" and "apresuntado", respectively) cooked hams, reported by Baggio and Bragagnolo [28]. Greater values of oleic acid are desired for their hypocholesterolemic action because they have the advantage of not reducing the protective high-density (HDL) lipoproteins in human blood.

In contrast to MUFAs, emphasis has been placed on reducing the intake of saturated fatty acids (SFAs) because they are considered to be associated with increased cholesterol level. Palmitic acid (16:0) was the major SFA found in the "Queijo de Porco" samples, followed by stearic acid (18:0) and, in much smaller concentrations, myristic acid (14:0) (Table 3). However, among the SFA, palmitic and myristic acids attract the most attention because they are considered hypercholesterolemic, since they raise human blood levels of low-density lipoprotein (LDL) cholesterol, increasing the risk of atherosclerosis and leading to cardiovascular disease in man. Together, these two fatty acids accounted for $22.95 \%$ of total fatty acids, being lower than the mean average $(\sim 25 \%)$ observed by Baggio and Bragagnolo [28] for Brazilian sausages, cooked hams and restructured meat products.

For polyunsaturated fatty acids (PUFAs), the proportion (mean of $15.79 \%$ ) observed in the "Queijo de Porco" samples was similar to that found by Baggio and Bragagnolo [28] in Brazilian cooked hams and cooked and fermented sausages, although these authors had observed higher concentrations (20 to $24 \%$ ) of PUFAS in emulsified sausages (Frankfurter and Mortadella). Like those products, linoleic acids (C18:2 n6) was the major constituent found in the "Queijo de Porco" samples (Table 3).

Public health policies in most developed countries recommend population-wide decreases in the intake of trans-fatty acids and increases in the consumption of PUFAs, especially the long-chain $\mathrm{n}-3$ PUFA series, which are considered beneficial to human health. Nutritional recommendations by the World Health Organization suggest increased consumption of n-3 PUFA, ideally to achieve an n6:n-3 ratio between 4:1 and 5:1. According to Wood et al. [31], for a healthy diet the U.K.

Department of Health (1994) recommended that the polyunsaturated/saturated fatty acid ratio should be higher than 0.40 . In the present study, only one brand had PUFA/SFA ratio lower than that recommended value, whereas in general all samples showed an average of 0.48 . This ratio was similar to those reported by other researchers, such as Brazilian cooked sausage $(0.40)$, cooked ham (0.40), Mortadella (0.55) and salami (0.38).

Table 3.Mean ( \pm standard deviation) of the main fatty acids (\% of total fatty acids) and nutritional relevant ratios of "Queijo de Porco" samples.

\begin{tabular}{llllll}
\hline Characteristics & Brand A & Brand B & Brand C & Brand D & Mean \\
\hline \multicolumn{2}{l}{ Saturated fatty acids (SFAs) } & & & & \\
C14:0 & $1.25 \pm 0.02$ & $1.21 \pm 0.07$ & $1.11 \pm 1.02$ & $1.09 \pm 0.37$ & $1.16 \pm 0,07$ \\
C16:0 & $22.89 \pm 0.88$ & $21.71 \pm 0.15$ & $21.69 \pm 0.57$ & $20.86 \pm 0.82$ & $21.79 \pm 0,83$ \\
C17:0 & $0.35 \pm 0.00^{a b}$ & $0.34 \pm 0.00^{b}$ & $0.40 \pm 0.01^{a}$ & $0.23 \pm 0.02^{c}$ & $0.33 \pm 0,07$
\end{tabular}


OLIVEIRA,C. A. de; RODRIGUES, L. M.; ANDRADE, M. P. D.; RAMOS, A. de L. S.; RAMOS, E. M. (2019)

Technological and Nutritive Characterization of "Queijo de Porco" Sausage Traditionally Produced and Commercialized in Southern Brazil
C18:0
$9.86 \pm 0.19^{a}$
$9.29 \pm 0.10^{a b}$
$9.65 \pm 0.30^{a}$
$8.78 \pm 0.16^{b}$
$9.39 \pm 0,47$
C21:0
$0.47 \pm 0.02^{b}$
$0.59 \pm 0.00^{a}$
$0.60 \pm 0.01^{a}$
$0.56 \pm 0.03^{a}$
$0.55 \pm 0,05$

Monounsaturated fatty acids

(MUFAs)

$\begin{array}{llllll}\text { C16:1 } & 2.79 \pm 0.10^{a} & 2.14 \pm 0.04^{b} & 2.67 \pm 0.45^{b} & 2.16 \pm 0.08^{b} & 2.44 \pm 0,33 \\ \text { C17:1 } & 0.34 \pm 0.01^{a} & 0.33 \pm 0.00^{a} & 0.31 \pm 0.00^{a} & 0.24 \pm 0.02^{b} & 0.30 \pm 0,04 \\ \text { C18:1 } & 43.79 \pm 1.61^{a b} & 44.18 \pm 0.00^{a} & 40.93 \pm 0.72^{b} & 42.63 \pm 0.40^{a b} & 42.88 \pm 1,45 \\ \text { C20:1 } & 0.94 \pm 0.02^{a} & 0.83 \pm 0.01^{b} & 0.79 \pm 0.00^{b c} & 0.78 \pm 0.01^{c} & 0.83 \pm 0,07\end{array}$

Polyunsaturated fatty acids

(PUFAs)

$\begin{array}{llllll}\text { C18:2 n6 } & 11.27 \pm 0.17^{b} & 14.65 \pm 0.01^{a} & 16.04 \pm 0.73^{a} & 16.15 \pm 0.81^{a} & 14,53 \pm 2,27 \\ \text { C18:3 n6 } & 0.43 \pm 0.01^{b} & 0.78 \pm 0.00^{a} & 0.79 \pm 0.04^{a} & 0.82 \pm 0.04^{a} & 0.70 \pm 0,18 \\ \text { C18:3n3 } & 0.48 \pm 0.02^{a} & 0.59 \pm 0.01^{b} & 0.58 \pm 0.01^{b} & 0.60 \pm 0.00^{b} & 0.56 \pm 0,05\end{array}$

Total fatty acids

$\begin{array}{llllll}\Sigma \text { SFA } & 34.78 \pm 1.14^{a} & 33.19 \pm 0.40^{a b} & 33.46 \pm 1.43^{a b} & 31.52 \pm 0,02^{b} & 33,24 \pm 1,34 \\ \text { IMUFA } & 47.86 \pm 2,90^{a} & 47.48 \pm 0.08^{a} & 44.70 \pm 1.15^{b} & 45.81 \pm 0.01^{b} & 46.46 \pm 1,47 \\ \text { IPUFA } & 12.18 \pm 0.17^{b} & 16.02 \pm 0.03^{a} & 17.41 \pm 1,04^{a} & 17.57 \pm 0.01^{a} & 15.79 \pm 2,50 \\ \text { Ratio PUFA/SFA } & 0.35 \pm 0.07^{b} & 0.48 \pm 0.02^{a} & 0.52 \pm 0.07^{a} & 0.55 \pm 0.02^{a} & 0.48 \pm 0,09 \\ \text { Indexes } & & & & \\ \text { Atherogenic } & 0.46 \pm 0.03^{a} & 0.42 \pm 0.01^{b} & 0.42 \pm 0.02^{b} & 0.41 \pm 0.01^{b} & 0.43 \pm 0.01 \\ \text { Trombogenic } & 1.09 \pm 0.05^{a} & 0.97 \pm 0.01^{a b} & 1.00 \pm 0.19^{a b} & 0.95 \pm 0.02^{b} & 1.00 \pm 0,07\end{array}$

${ }^{a \cdot c}$ Means followed by different letters in the same roware different $(P<0.05)$ by the Tukey's test.

Although the PUFA/SFA ratio is one of the major parameters currently used to assess the nutritional quality of the lipid fraction of foods, this ratio has been replaced by the indices of atherogenicity (Al) and thrombogenicity ( $\mathrm{Tl})$. These indexes are considered a health indicators related to the risk of cardiovascular disease. Of the samples analyzed, only the "A" brand had higher levels than the others. However, the average values observed $(\mathrm{Al}=0.43$ and $\mathrm{TI}=1.00)$ are much lower than those reported $(\mathrm{Al}=0.50$ to 0.67 and $\mathrm{TI}=1.09$ to 1.45$)$ for some traditional Argentinean meat sausages by Romero et al. [32], which, according to these authors, are similar to the indices observed for Brazilian salami, Spanish salchichón and Italian salami.

Therefore, with respect to fatty acid composition, it can be concluded that the regional "Queijo de Porco" products show a similar MUFA content and PUFA/SFA ration to that reported in the literature for Brazilian pork products. However, they presented lower atherogenicity and thrombogenicity indexes, which are very important from a nutritional point of view, since the type of fat is more important than the total amount of fat in the quantification of cardiovascular diseases risk. 
OLIVEIRA,C. A. de; RODRIGUES, L. M.; ANDRADE, M. P. D.; RAMOS, A. de L. S.; RAMOS, E. M. (2019)

Technological and Nutritive Characterization of "Queijo de Porco" Sausage Traditionally Produced and Commercialized in Southern Brazil

\section{Conclusões}

Despite the similarities, there is no standardization in the production of "Queijo de Porco" in Brazil, possibly due to the fact of the variability between the origins and regional characteristics where each product was produced. Moreover, the chemical composition of the products evaluated does not permit to categorize them as "Fiambres" or any other designation according to the Brazilian legislation.

The analyzed products show high protein and iron contents, with good amount of MUFA and PUFA, and low atherogenic and thrombogenic indexes, which make them more healthful products than some pork products produced in Brazil. However, it is clear the necessity of more studies about this product in order to establish standards that can sustain the regulations from the Ministry of Agriculture, which could provide more dissemination of it, permitting the industries of the sector add value to less specialized cuts of pork, but at the same time provide a product with considerable nutritional value.

\section{Acknowledgements}

The authors would like to thank the Fundação de Amparo à Pesquisa do Estado de Minas Gerais (FAPEMIG; CVZ APQ-02015-15) and the Conselho Nacional de Desenvolvimento Científico e Tecnológico (CNPq; MCT 430206/2016-0) for their financial support.

\section{Referências}

[1] OCKERMAN HW, HANSEN CL. Animal by-product processing \& utilization. Boca Raton: CRC Press, 2000; pp. 523.

[2] COLOMBIA. Ministério de La Salud. Reglamento parcial el titulo V de la ley 09 de 1979, en cuanto a producción, procesamiento, transporte y expendio de los productos cárnicos procesados. Decreto, n²162, Agosto 1, 1983, Republica de Colombia, 1983.

[3] PEARSON AM, GILLETT TA. Processed meats. 3 ed. New York: Chapman \& Hall, 1999; pp. 664.

[4] URUGUAY. 1egulamento Bromatologico Nacional. Decreto, $n^{\circ} 315 / 994$, Julio 5, 1994, Republica Oriental del Uruguay, 1994.

[5] MEXICO. Calidad para queso de puerco. Normas Mexicanas, NMX-F-141, 1969, Dirección General de Normas., 1969.

[6] COSTA RICA. Norma Oficial de Productos Cárnicos: Clasificación y características. Decreto Ejecutivo, nº 18341, Agosto 8, 1988, Imprenta Nacional, Gaceta nº 149, RTCR 79, 1988. 
OLIVEIRA,C. A. de; RODRIGUES, L. M.; ANDRADE, M. P. D.; RAMOS, A. de L. S.; RAMOS, E. M. (2019)

Technological and Nutritive Characterization of "Queijo de Porco" Sausage Traditionally Produced and Commercialized in Southern Brazil

[7] EQUADOR. Instituto Ecuatoriano de Normalización, INEN. Carne y productos cárnicos. Queso de cerdo. Requisitos. Norma Técnica Ecuatoriana, NTE - INEN 1338, 2012, INEN, 2012.

[8] AOAC. Official methods of analysis of AOAC International. 19th ed. Gaithersburg, MD: Association of Official Analytical Chemists, 2012; pp. 1298.

[9] RAMOS EM, GOMIDE LAM. Avaliação da Qualidade de Carnes: Fundamentos e Metodologias. 2a ed. Viçosa: Editora UFV, 2017; pp. 473.

[10] HARTMAN L, LAGO RC. Rapid preparation of fatty acid methyl esters from lipids. Lab Pract. $1973 ; 22(6): 475-6$.

[11] VICENTE-NETO J, BRESSAN MC, FARIA PB, JO EV, CARDOSO M, GLORIA MB et al. Fatty acid profiles in meat from Caiman yacare (Caiman crocodilus yacare) raised in the wild or in captivity. Meat Sci. 2010;85(4):752-8. doi:10.1016/j.meatsci.2010.03.036

[12] ULBRICHT TLV, SOUTHGATE DAT. Coronary heart disease: seven dietary factors. The Lanc. 1991;338(8773):985-92. doi:10.1016/0140-6736(91)91846-M

[13] BRASIL. Ministério da Agricultura, Pecuária e Abastecimento (MAPA), Secretaria de Defesa Agropecuária (SDA). Aprova os Regulamentos Técnicos de Identidade e Qualidade de Almôndega, de Apresuntado, de Fiambre, de Hambúrguer, de Kibe, de Presunto Cozido e de Presunto. Instrução Normativa, 20, 31 de julho de 2000, Diário Oficial [da] República Federativa do Brasil, 2000.

[14] BRASIL. Ministério da Agricultura, Pecuária e do Abastecimento (MAPA) Secretaria de Defesa Agropecuária (SDA). Aprova o Regulamento da Inspeção Industrial e Sanitária de Produtos de Origem Animal (RIISPOA). Decreto, $n^{\circ}$ 30.691, 29 de março de 1952 e alterado pela ultima vez pelo Decreto no. 2.244, de 4 de junho de 1997, Diário Oficial [da] República Federativa do Brasil, 1997.

[15] OCKERMAN HW. Sausage and Processed Meat Formulations. 1st ed. New York: Van Nostrand Reinhold, 1989; pp.

[16] BAYLEY AJ, LIGHT ND. Connective tissue in meat and meat products. England Elsevier Science Publishers, 1989; pp. 355.

[17] PEGG RB, SHAHIDI FS. Nitrite curing of meat: the $\mathrm{N}$-nitrosamine problem and nitrite alternatives. 1 ed. Trumbull, USA: Wiley-Blackwell, 2000; pp. 268.

[18] HONIKEL KO. The use and control of nitrate and nitrite for the processing of meat products. Meat Sci. 2008;78(1-2):68-76. doi:10.1016/j.meatsci.2007.05.030 
OLIVEIRA,C. A. de; RODRIGUES, L. M.; ANDRADE, M. P. D.; RAMOS, A. de L. S.; RAMOS, E. M. (2019)

Technological and Nutritive Characterization of "Queijo de Porco" Sausage Traditionally Produced and Commercialized in Southern Brazil

[19] BRASIL. Ministério da Agricultura, Pecuária e Abastecimento (MAPA) Secretaria de Defesa Agropecuária (SDA). Aprova o Regulamento Técnico de Atribuição de Aditivos, e seus Limites das seguintes Categorias de Alimentos 8: Carne e Produtos Cárneos. Instrução Normativa no. 51, 29 dezembro de 2006, Diário Oficial [da] República Federativa do Brasil, 2006.

[20] WHO. Reducing salt intake in populations. Report of a WHO Forum and Technical Meeting. Paris: World Health Organization, 2006; pp.

[21] GOMIDE LAM, RAMOS EM, FONTES PR. Ciência e Qualidade da Carne: Fundamentos. 1 ed. Viçosa: Editora UFV, 2013; pp. 197.

[22] USDA. USDA National Nutrient Database for Standard Reference: USDA/ARS Nutrient Data Laboratory, Release 19; 2007 [cited 2007 May, 05, 2014]. Available from: http://www.ars.usda.gov/ba/bhnrc/ndl.

[23] JIMÉNEZ-COLMENERO F, CARBALLO J, COFRADES S. Healthier meat and meat products: their role as functional foods. Meat Sci. 2001;59:5-13. doi:10.1016/S0309-1740(01)00053-5

[24] IOM/FNB. Dietary Reference Intakes for Vitamin A, Vitamin K, Arsenic, Boron, Chromium, Copper, lodine, Iron, Manganese, Molybdenum, Nickel, Silicon, Vanadium, and Zinc : a Report of the Panel on Micronutrients external link disclaimer. Board. IoMFaN, editor. Washington, DC: National Academy Press, 2001; pp.

[25] IOM/FNB. Dietary Reference Intakes for Calcium and Vitamin D. Board. IoMFaN, editor. Washington, DC: National Academy Press, 2011; pp.

[26] MASSINGUE AA, TORRES FILHO RDA, FONTES PR, RAMOS ADLS, FONTES EAF, OLALQUIAGA PEREZ $J R$ et al. Effect of mechanically deboned poultry meat content on technological properties and sensory characteristics of lamb and mutton sausages. Asian-Australas J Anim Sci. 2018;31(4):576-84. doi:10.5713/ajas.17.0471

[27] KOOLMEES PA, BIJKER PG, VAN LOGTESTIJN JG, TUINSTRA-MELGERS J. Histometrical and chemical analysis of mechanically deboned pork, poultry and veal. J Anim Sci. 1986;63:1830-7.

[28] BAGGIO SR, BRAGAGNOLO N. Lipid fraction quality evaluation of Brazilian meat-based products. J Braz Chem Soc. 2008;19:463-70.

[29] WILLIAMSON CS, FOSTER RK, STANNER SA, BUTTRISS JL. Red meat in the diet. Nutr Bull. 2005;30(4):323-55. doi:10.1111/j.1467-3010.2005.00525.x 
OLIVEIRA,C. A. de; RODRIGUES, L. M.; ANDRADE, M. P. D.; RAMOS, A. de L. S.; RAMOS, E. M. (2019)

Technological and Nutritive Characterization of "Queijo de Porco" Sausage Traditionally Produced and Commercialized in Southern Brazil

[30] WHO. Diet nutrition and the prevention of chronic diseases: report of a Joint WHO/FAO Expert Consultation2002; pp. 149.

[31] WOOD JD, RICHARDSON RI, NUTE GR, FISHER AV, CAMPO MM, KASAPIDOU E et al. Effects of fatty acids on meat quality: a review. Meat Sci. 2004;66(1):21-32. doi:10.1016/S0309-1740(03)00022-6

[32] ROMERO MC, ROMERO AM, DOVAL MM, JUDIS MA. Nutritional value and fatty acid composition of some traditional Argentinean meat sausages. Food Sci Tech. 2013;33:161-6. 